\title{
Erosion Related Changes to Physicochemical Properties of Ultisols Distributed on Calcareous Sedimentary Rocks
}

\author{
Arpita Nandi ${ }^{1} \&$ Ingrid Luffman ${ }^{1}$ \\ ${ }^{1}$ East Tennessee State University, Johnson City, United States \\ Correspondence: Arpita Nandi, East Tennessee State University, Johnson City TN 37614, United States. E-mail: \\ nandi@etsu.edu
}

Received: May 22, 2012 Accepted: July 10, 2012 Online Published: July 20, 2012

doi:10.5539/jsd.v5n8p52 URL: http://dx.doi.org/10.5539/jsd.v5n8p52

\begin{abstract}
Water induced soil erosion, relating to improper land management, is a serious land degradation problem in Ultisols that results in rill and gully erosion. The extent of land degradation depends largely on the severity of erosion, which modifies the soil's physical and chemical properties. A detailed understanding of eroded soil properties is essential for assessment of future land management and soil-water conservation. The aim of this research is to evaluate the changes in physico-chemical and mineralogical properties of ultisols associated with gully erosion in East Tennessee. The study area is located in the southern Appalachian Valley and Ridge province, where a thick sequence of red colored clay rich soil (soil series is the Collegedale-Etowah complex) is found on dolomite and limestone bedrock. Four one-meter long soil cores and fifty-two bulk samples were collected from sites of active gully erosion (two cores) and from adjacent non-gullied soil (two cores). The physico-chemical properties assessed for each sample included clay mineralogy using X-ray diffraction (XRD), scanning electron microscopy (SEM) with energy-dispersive X-ray (EDX) methods, pH, cation exchange capacity (CEC), nitrogen, potassium, and phosphorus, particle size distribution (PSD), Atterburg limits, bulk density, moisture content, porosity, saturated hydraulic conductivity (Ks), soil erodibility factor, and swelling potential. According to the USDA, soil texture was classified as silty clay loam and silty clay. Significant differences $(\mathrm{p}<0.05)$ existed between eroding and non-eroding soils for the following factors: clay and silt content; porosity Ks, K; Atterberg limits, and swelling potential. Statistically significant correlations were established between clay content and Atterberg limits, bulk density, Ks, and swelling potential. Furthermore, results of X-ray diffraction indicated the presence of quartz, chlorite, illite, kaolinite, kaolinite - smectite expansive clay, hematite and ferrihydrite. Relic crystals of calcite were found in the saprolite horizon. Overall result indicated that selected physico-chemical properties can be used as an indicator of gully erosion in southern Appalachian Ultisols.
\end{abstract}

Keywords: gully erosion, physico-chemical properties, clay minerals, atterberg limit, swelling potential, XRD, SEM, ultisol

\section{Introducation}

Water induced soil erosion reduces soil's productivity in terms of plant nutrient, water-holding capacity and hydraulic conductivity. In more severe cases erosion involves the removal of sediments from civil structures like roads, culverts, ponds, lakes and other surface water bodies, disruption of aquatic ecosystems and contamination of drinking water supplies (O'Geen \& Schwankl, 2006). In the United States, approximately 2.4 billion tons of soil/year are deposited in the surface water bodies (Pimentel, 2000), resulting in 6,142 waterbodies (streams, lakes or reservoirs) listed as impaired due to the presence of sediment nationwide, including 5,953 miles of sediment-impaired streams in Tennessee alone (Tennessee Water Quality Assessment Report, 2012). There are three types of water induced soil erosion: sheet, rill and gully erosion (O'Geen \& Schwankl, 2006). Among them, gully erosion poses the great challenge to geologists, soil scientists, forest conservationists and engineers, and afforestation can fail to restore the landscape (Lal, 2001). Gully erosion begins when runoff concentrates into channels, and results in the development of rills that enlarge into deep trenches in the land surface over time.

Gully formation and morphology are frequently correlated with physiographic, climatic and anthropogenic factors such as topography, precipitation, vegetation and land use (Lal, 2001; Cerda A, 2002). Assessment of gully erosion is often based on soil erodibility, an estimate of the soil's ability to resist erosion based on the integrated effect of rainfall, runoff, and infiltration (Lal, 2001). Models and indices used to estimate soil 
erodibility include the soil erodibility factor (Zhang et al., 2003; Liu, 2003), the universal soil loss equation (USLE) (Cauley, 1986), revised USLE (Fistikoglu \& Harmancioglu, 2002), and modified USLE (Nearing et al., 2005), soil loss estimation models (Smith et al., 2000), and other measures to assess aggregate stability (Oades \& Waters, 1991; Amézketa, 1999; Rienks et al., 2000). Erosion reduces soil stability and nutrient efficiency by altering the soil's physical, chemical, and biological properties (Lal, 2001; Lobo et al., 2005; Santis et al., 2010), which are important factors in badland gully erosion, especially in clay-rich soils(Bryan \& Yair, 1982; Imeson et al., 1982; Ingles \& Aitchson,1969; Okagbue et al., 1988; Santis et al., 2010).

The correlation of gully erosion severity with soil intrinsic physico-chemical factors is asserted in the literature (Nordström, 1988; Lal, 2001, Battaglia, et al., 2002; Summa et al., 2007, Rienks et al., 2000; Piccarreta, 2006; Singh \& Prakash, 2000). Further, the state of soil dispersion and erodibility in erosion prone areas has been related to the exchangeable sodium percentage (ESP), the sodium adsorption ratio (SAR), the sodium percentage (PS) and the total amount of dissolved salts (TDS) of the surface soils (Faulkner, 2006; Piccarreta et al., 2006; Torri et al., 1994), although gullying occurs in soils that do not exceed the erosion threshold for these parameters (Rienks, 2000).

While studies that assess the relationship between soil properties and erosion are widespread, few have quantified these relationships. Rienks (2000) examined soil physico-chemical properties and gully erosion in South Africa, concluding that erodibility was related to dispersion rather than lateral subsurface flow and piping. Igwe and Ejiofor (2005) related the structural stability of gully walls to soil physical properties, and found that low Atterberg limits were related to slumping of gully walls. Others assert that severely eroded soils tend to have more clay, less organic matter, and a lower moisture content than non-eroded soils (Nizeyimana \& Olson, 1988; Rhoton \& Tyler, 1990). A characterization of the change in soil properties resulting from a gradual erosion of surface and subsurface soil is needed, because a thorough understanding of erosion induced changes in soil properties is essential for effective planning, land management and conservation (Van-Zijl, 2010). In this regard, this study investigates the properties of eroding and non-eroding Ultisols in the Southern Appalachian Valley and Ridge physiographic province. The study involves soil analysis from subsurface soil horizons, by comparing their physical and chemical behavior from deep active eroding sites and adjacent non-eroding sites. The results of this study may be used to better understand how vegetation, soil chemistry, soil structure and erosion are related and lead to better gully management practices in similar soil.

\section{Study Area and Method}

\subsection{Study Area}

Carbonate (limestone and dolostone) derived Ultisols comprise approximately $20 \%$, of the total land area of the contiguous United States (including Tennessee, Georgia, Montana, and Florida) (Stiles \& Stensvold, 2007). Generally distributed on slopes of undulating karst landforms, Ultisols support agriculture and pasture land uses, and they are encountered as earth materials in both land reclamation and civil engineering projects. Soil erosion is a serious land degradation problem in this soil, and is often associated with improper land management practices (Boero, 1989). Erosion in Ultisols commonly takes the form of rill and gully erosion which is typical for fine grained silty and clayey soils (Zhang et al., 2003).

A 0.58 square $\mathrm{km}$ (144 acre) plot of land located in Washington County, Tennessee, surrounding the East Tennessee State University Valleybrook research facility ( $\left.+36^{\circ} 25^{\prime} 36.77^{\prime \prime},-82^{\circ} 32^{\prime} 10.63 "\right)$ (Figure 1a), was chosen as a case study area. The facility comprises forest and pasture land, surrounded by agricultural and residential property. A study of historical aerial photographs from 1956, 1976, 1984, 1988, 1992, 1997, and 2006 indicates mix of forest and pasture land cover existed at least from 1956 through the present. In 1983 the land was acquired as a research facility for animal nutrient supplements and from 1986 through 2010, land use in the study site was primarily cattle grazing and hay pasture with land cover of pasture grass interspersed with patches of brush and small trees (S \& ME, 2010). Evidence of erosion appears first in the 1988 photograph, identified by an increase in albedo associated with loss of vegetative cover and surface soil exposure that typically precedes erosion. Based on the evidence from the aerial photographs, we conclude that the site has experienced at least twenty four years of undisturbed erosional history unmodified by any efforts to correct or halt the erosion. Hence, the undisturbed active gully areas in the facility are ideal candidates for the present study (Figure 2).

The geomorphology of the Valleybrook facility is dominated by fluviokarst topography developed in soluble carbonate bedrock known as the Knox Limestone and Honaker Dolomite group. The rock is $762 \mathrm{~m}$ to $1,067 \mathrm{~m}$ (2,500 to 3,500 ft) thick, Ordovician to Cambrian aged, siliceous dolomite and magnesian limestone sequence (Moore, 1976), with isolated blocks of calcareous shale (Sevier Shale formation) which were transported from the ridges of the slopes by gravity. The rock is folded and faulted into a long northeast-southwest trending 
pattern. Through differential erosion, the Knox, Honaker and Sevier formations have developed into the Valley and Ridge topography, and weathering of carbonate rock has produced the residual clay-rich Ultisols of the Collegedale-Etowah complex (CeD3) (USDA Web Soil Survey, 2011) (Figure 1b). Soil thickness varies from a few $\mathrm{cm}$ to as thick as $2.0 \mathrm{~m}$ (78.74 inches). Collegedale-Etowah is characterized by silty clay loam and silty clay textures (USDA Web Soil Survey, 2011). Generally, this soil is found at moderately high elevations, ranging from $189 \mathrm{~m}$ to $365.7 \mathrm{~m}$ (620 ft to $1,200 \mathrm{ft})$ above sea level. During periods of excessive precipitation the Collegedale-Etowah soil unit is moderately sensitive to weathering and erosion leading to gully formation. Field reconnaissance supports the soil unit description in the USDA Soil Survey report indicating this area is prone to severe erosion and unsuitable for agriculture and road construction (USDA Web Soil Survey, 2011). The reported average erosion factor for $\mathrm{CeD} 3$ is 0.28 indicating the soil is susceptible rill and gully erosion by water (USDA Web Soil Survey, 2011).

East Tennessee has a Humid Subtropical climate (Cfa Köppen climate classification), characterized by hot summers, mild winters and year round precipitation. The average temperature ranges from $1.1^{\circ} \mathrm{C}\left(34^{\circ} \mathrm{F}\right)$ in January to $23.3^{\circ} \mathrm{C}\left(74^{\circ} \mathrm{F}\right)$ in July. The average monthly rainfall is $8.6 \mathrm{~cm}(3.4$ inches), with annual totals ranging from $91.4 \mathrm{~cm}$ to $116.8 \mathrm{~cm}$ (36 to 46 inches). Currently the study area lies fallow, and evidence of past grazing is visible with sparse vegetation adjacent to patches of tall grass and briars. Approximately $10 \%$ of the site is deciduous forest, and soils are well drained with no evidence of obvious fragipans. Evidences of subsurface tunnel erosion were observed in the site, where roof of the tunnels collapse and accelerate gully erosion.



Figure 1. Location map (a), sample locations for non-eroding site are 1 and 2, sampling locations for eroding sites are 3 , and 4 and soil map of the area (b)

East Tennessee has a Humid Subtropical climate (Cfa Köppen climate classification), characterized by hot summers, mild winters and year round precipitation. The average temperature ranges from $1.1^{\circ} \mathrm{C}\left(34^{\circ} \mathrm{F}\right)$ in January to $23.3^{\circ} \mathrm{C}\left(74^{\circ} \mathrm{F}\right)$ in July. The average monthly rainfall is $8.6 \mathrm{~cm}(3.4$ inches), with annual totals ranging from $91.4 \mathrm{~cm}$ to $116.8 \mathrm{~cm}$ (36 to 46 inches). Currently the study area lies fallow, and evidence of past grazing is visible with sparse vegetation adjacent to patches of tall grass and briars. Approximately $10 \%$ of the site is 
deciduous forest, and soils are well drained with no evidence of obvious fragipans. Evidences of subsurface tunnel erosion were observed in the site, where roof of the tunnels collapse and accelerate gully erosion.

\subsection{Sampling Procedures}

The sampling site comprises two severely gullied and two non-gullied locations in the Collegedale-Etowah soil series. A preliminary soil observation was performed in the field to identify Munsell soil color, soil structure, $\mathrm{pH}$, and carbonate content test. Four soil cores and a series of bulk samples were collected from the area. Among the

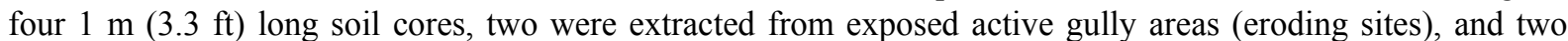
from the adjacent soil which showed no evidence of past gully erosion (non-eroding sites). Each core was $5 \mathrm{~cm}$ ( 2 inch) in diameter and was portioned into thirteen $7.5 \mathrm{~cm}(3 \mathrm{inch})$ long intervals (starting from $0 \mathrm{~cm}, 7.5 \mathrm{~cm}$, $15 \mathrm{~cm}, 22.5 \mathrm{~cm}, 30 \mathrm{~cm}, 37.5 \mathrm{~cm}, 45 \mathrm{~cm}, 52.5 \mathrm{~cm}, 60 \mathrm{~cm}, 67.5 \mathrm{~cm}, 75 \mathrm{~cm}, 82.5 \mathrm{~cm}$, and up to $100 \mathrm{~cm}$ ), yielding a total of fifty-two core samples. A check for compaction was made for each core before removing the sampler from the soil by removing the sampler's handle and inspecting the relative height of soil inside and outside the sampler. The soil cores were sealed immediately in the field and were transferred to the laboratory for analysis. Fifty-two additional bulk samples were collected at the coring sites, at depths matching the core sample depths. The additional bulk samples were necessary to provide a sufficiently large volume of soil to complete the laboratory tests. Of the fifty two bulk samples, twenty-six were collected from the eroding gully complex, and twenty-six were collected from the non-eroding vicinity. The bulk samples were collected in sterile polythene bags and transported to the laboratory for processing.
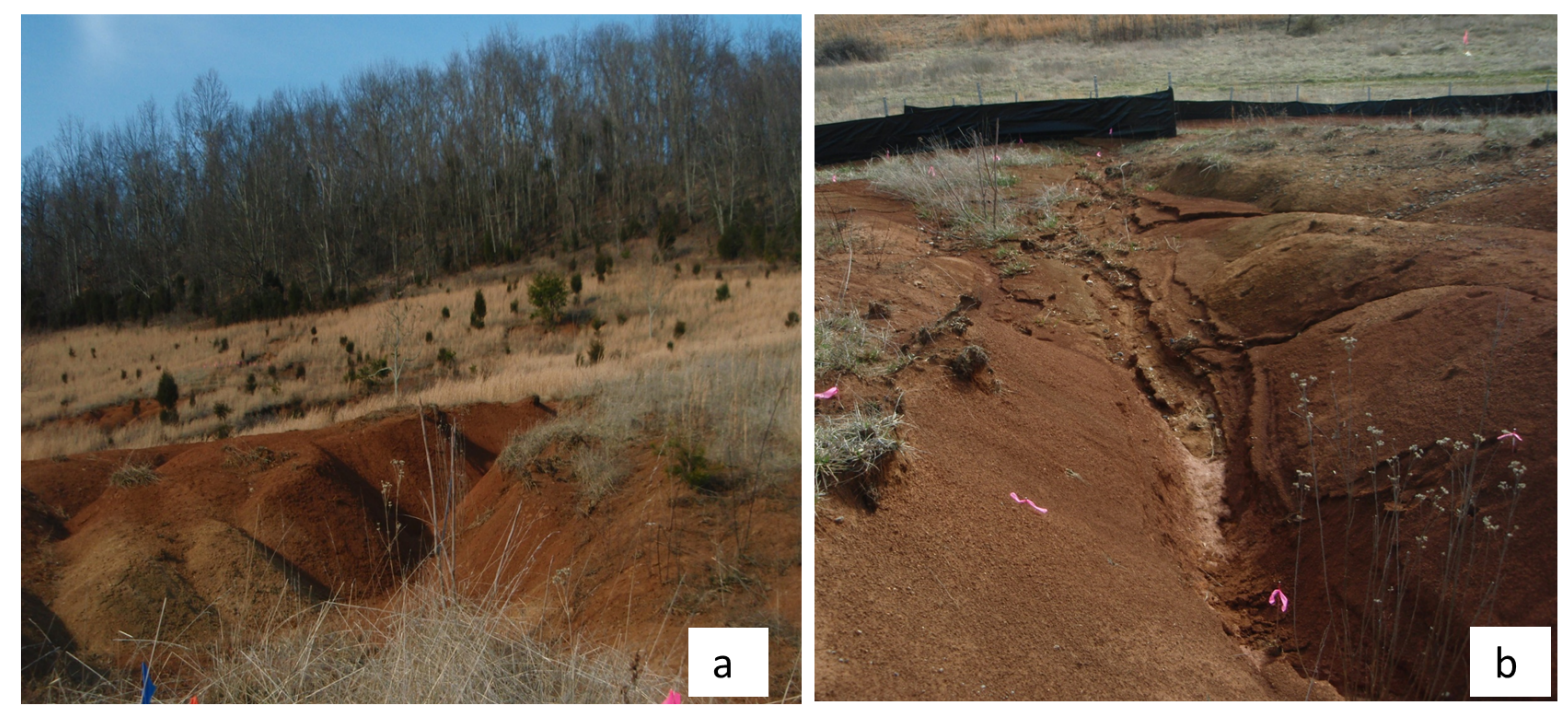

Figure 2. Gully erosion looking upslope (a), and looking downslope (b) in the study area

\subsection{Sample Preparation and Physico-chemical Analysis Methods}

In the laboratory, the core samples were analyzed to determine the following physico-chemical characteristics: $\mathrm{pH}$; cation-exchange capacity (CEC); Nitrogen (N), Potassium (K), and Phosphorus (P) content; bulk density; moisture content; porosity; saturated hydraulic conductivity (Ks); and swelling potential, because these tests are sensitive to soil disturbance from bulk sampling procedure. The bulk samples were air-dried and clay mineralogy was determined using X-ray diffraction (XRD) and scanning electron microscopy (SEM) with energy-dispersive X-ray (EDX) methods. The bulk samples were also used to determine particle size distribution (PSD) and Atterberg limits. A 3\% to 9\% soil compaction was noticed in the soil cores, an unavoidable result of friction between the soil and corer. Compaction may affect bulk density, porosity and Ks, however it is assumed that uniform compaction throughout the coring process does not affect the general trend of the results.

Particle size distribution analysis (PSD) was performed using sieve and hydrometer analysis to determine the gradation (distribution of soil particles, by size) within a given sample. PSD analysis was performed following USDA 3A1 method (Soil Survey Investigations Report No. 42, Soil Survey Laboratory Methods Manual, Version 4.0, November 2004, USDA, NRCS) and the result was plotted using a USDA Soil Texture Triangle. Atterberg limits (liquid limit (LL), plastic Limit (PL) and plasticity index (PI)) were measured on the portion of 
the sample that passed through a 425- $\mu \mathrm{m}$ (No. 40) sieve using the ASTM D4318 method (ASTM, 1996). Bulk density was calculated as the ratio of the weight of each core sample to its volume $(7.5 \mathrm{~cm}$ long, and $5 \mathrm{~cm}$ in diameter) (Blake, 1986). Moisture content was measured using the ASTM D 4643 method (ASTM, 1996). Differential swell tests were performed on the samples using water and kerosene as solvents for the clay minerals. The degree of swelling was the difference between the initial and final volume of the soil after a period of 24 hours (IS: 2720, 1997). Total porosity was calculated in undisturbed core samples using Danielson's method (Danielson, 1986). The Ks was measured using a constant head permeameter according to the ASTM D 2434 method (ASTM, 1996). The soil erodibility factor commonly used in the Universal Soil Loss Equation (USLE) was determined using the nomograph of Wischmeier and Smith (1978), which estimates K from five soil and soil-profile parameters: percent modified silt $(0.002-0.1 \mathrm{~mm})$, percent sand $(0.1-2 \mathrm{~mm})$, percent organic matter $(\mathrm{OM})$, soil structure class (s) and soil permeability class (p). The structure and permeability classes and groups of classes were taken from the Soil Survey Manual (USDA, 1951).

Mineralogical analyses were carried out on the clay fraction of powdered soil samples. The clay fraction was separated by means of fractioned sedimentation in accordance with Stokes' law. Samples were analyzed on a Shimadzu XRD 6000 diffractometer run at $40.0 \mathrm{kV}$ and $30.0 \mathrm{~mA}$. Data were collected over a $2 \theta$ range of $5^{\circ}-45^{\circ}$ with a continuous scan of $2.0^{\circ} \mathrm{min}$ and $0.02^{\circ}$ sampling pitch. XRD peaks (reported as $2 \theta^{\circ}$ ) were converted to d-spacings (in $\AA$ ) using Bragg's Law. Scanning electron microscopy (SEM) and energy-dispersive X-ray (EDX) microanalysis, completed on an FEI Quanta ESEM, complemented the XRD studies. Spot scans and whole sample scans were performed using the dispersive X-ray (EDX) system for elemental analysis. The SEM-EDX analysis was used to (1) determine the elemental composition, and (2) confirm the presence of various minerals in the bulk samples.

In accordance with methods outlined in the Soil Survey Laboratory Methods Manual (USDA, 2004), soil pH was determined in the field using $\mathrm{pH}$ meter, and also tested in the laboratory using indicator dye. Cation Exchange Capacity (CEC) was estimated through correlation with clay content (Weil, 2005). Nitrogen, Phosphorus and Potassium content were estimated using indicator dyes. The physical, chemical and mineralogical properties of the soil samples with respect to various soil horizons are summarized in Tables 1 and 2. To compare eroding versus non-eroding soils for the variables of interest, a Univariate Analysis of Variance was conducted in SPSS, using depth and eroding status as factors and the cores as replicates. Depth was included as a factor because the variables tended to be correlated with depth. Spearman's correlation coefficients were calculated to quantify the relationship between variables (Table 3 ).

\section{Results and Discussion}

\subsection{Soil Profile}

Throughout the study area, the bedrock/soil interface was irregular due to pinnacles of rock protruding into the soil, and occasionally exposed at the surface (Moore, 1976). The field analysis revealed that the soil profiles had obvious soil layers, and four soil horizons were identified. In the non-eroding site, the surface horizon $(\mathrm{O})$ was very thin, present only to a depth of $2 \mathrm{~cm}(0.78 \mathrm{in})$. The underlying A horizon, from a depth of $2-19 \mathrm{~cm}(0.78-$ $7.48 \mathrm{in}$ ) consisted of a dark orange to reddish brown fine to coarse grained, granular, loose sand. The B horizon, located at a depth of $19-80 \mathrm{~cm}$ (7.48 in - $31.5 \mathrm{in}$ ), was characterized by illuviated fine grained massive clay. Below the B horizon, a probable saprolite zone (C horizon) consisting of partially altered carbonate rocks was present, which graded into the parent carbonate bedrock. The thickness of the saprolite zone could not be established, because the $\mathrm{C}$ horizon extended beyond the sampling depth.

The soil horizons in the eroding site were less well defined, because the soil was profoundly disturbed by slumping along the gully walls. The $\mathrm{O}$ horizon was non-existent due to active erosion, and therefore the $\mathrm{A}$ horizon extended from 0-50 $\mathrm{cm}(0-19.7 \mathrm{in})$ in depth, and was dominated by granular, non-cohesive, reddish brown colored sand. An abrupt change in grain size distribution from sand-dominated to clay-dominated soil marked the upper boundary of the B horizon which extended from 50- $80 \mathrm{~cm}(19.7-31.5 \mathrm{in})$ in depth, and graded into the $\mathrm{C}$ horizon.

\subsection{Soil Texture, Color and Atterberg Limits}

Soil texture is an important factor in soil erodibility because soil texture determines the consistence, cohesion, and mobility of the soil. PSD analysis to determine soil texture (Figure $3 a$ and $b$ ) indicates variation between eroding and non-eroding sites. The soil samples from the non-eroding sites were sandy loam to clay loam, and silty clay loam while samples from the eroding sites consisted of sandy loam to loam soil. In both the eroding and non-eroding sites, sand content decreased gradually with depth as the proportion of finer particles increased, partially due to illuviation and argillation in the B and C horizons (Brady \& Weil, 2008). Silt content was higher 
in the eroding sites $(43.3 \%)$ than in the non-eroding sites $(37.7 \%)(\mathrm{p}<0.000)$. The clay content of a soil plays a significant role in soil erosion; a clay content ranging from $10 \%$ to $40 \%$ helps in soil aggregation and reinforces soil stability, while a clay content of less than $10 \%$ interferes with cohesion and formation of soil aggregates, making the soil more vulnerable to raindrop impact (Ramezanpour et al., 2010). The average clay content of the eroding sites $(15.4 \%)$ was significantly lower than the clay content of the non-eroding sites $(26.3 \%)(\mathrm{p}<0.000)$. Examining the clay content by horizon, the clay fraction in the A horizon for the eroding sites was less than the $10 \%$ recommended (by Ramezanpour et al., 2010) for cohesion and the development of aggregates. For lower clay content potential for erosion may accelerate. The mechanism by which the clay is removed is not clear although evidence of eluviation/illuviation/argillation is there, obvious from increase in clay content with core depth. In addition to clay content, a soil's organic content enhances the stability of soil aggregates. Results indicate a very low organic content in the soil samples, which is expected in Ultisols with no vegetative cover. Inadequate organic matter damages soil structure, reduces water and nutrient holding capacity, and lessens the supply of plant nutrients such as nitrogen, phosphorus, potassium and sulfur.

Table 1. Physical properties of the core samples from non-eroding and eroding sites

\begin{tabular}{|c|c|c|c|c|c|c|c|c|c|c|c|c|c|c|}
\hline & 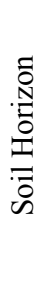 & 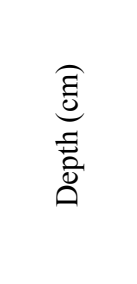 & 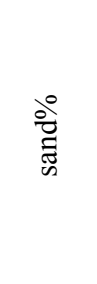 & 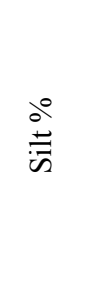 & $\begin{array}{l}\partial^{0} \\
\frac{\vec{\sigma}}{\circlearrowright}\end{array}$ & ヨ & $\underline{a}$ & $a$ & 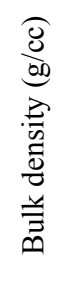 &  & $\begin{array}{l}0^{\circ} \\
\stackrel{\overrightarrow{0}}{0} \\
0 \\
0 \\
0\end{array}$ & 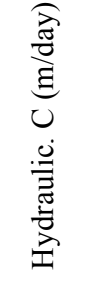 & $\begin{array}{l}\overline{\overline{0}} \\
\bar{b} \\
0^{\circ}\end{array}$ & 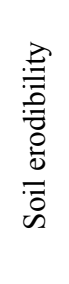 \\
\hline \multirow{8}{*}{ 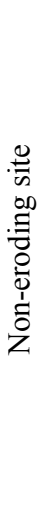 } & $\mathrm{O}$ & 0 to 2 & 65.00 & 30.00 & 5.00 & 35.00 & 25.14 & 9.86 & 1.22 & 20.00 & 38.00 & 7.89 & 1.05 & 0.29 \\
\hline & A & 2 to 18 & 58.00 & 35.00 & 7.00 & 26.50 & 15.30 & 11.20 & 1.29 & 22.12 & 39.00 & 8.54 & 5.20 & 0.31 \\
\hline & B & 18 to 76 & 50.38 & 40.13 & 9.50 & 34.25 & 23.20 & 11.05 & 1.23 & 18.50 & 49.50 & 15.70 & 22.66 & 0.33 \\
\hline & $\mathrm{C}$ & 76 to 100 & 22.00 & 38.00 & 40.00 & 28.56 & 10.92 & 17.64 & 1.48 & 27.10 & 35.00 & 5.41 & 18.23 & 0.24 \\
\hline & $\mathrm{O}$ & 0 to 1 & 62.00 & 33.00 & 5.00 & 30.12 & 25.16 & 4.96 & 1.25 & 22.50 & 40.00 & 8.73 & 2.50 & 0.30 \\
\hline & A & 1 to 19 & 50.40 & 35.80 & 13.80 & 30.20 & 20.15 & 10.05 & 1.31 & 23.20 & 40.00 & 9.87 & 9.57 & 0.29 \\
\hline & B & 19 to 80 & 47.29 & 39.14 & 15.57 & 41.00 & 19.11 & 21.89 & 1.45 & 24.86 & 40.29 & 7.68 & 21.02 & 0.26 \\
\hline & $\mathrm{C}$ & 80 to 100 & 29.00 & 35.00 & 36.00 & 25.06 & 12.50 & 12.56 & 1.50 & 26.00 & 40.00 & 8.50 & 13.20 & 0.26 \\
\hline \multirow{6}{*}{ 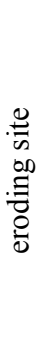 } & $\mathrm{A}$ & 0 to 48 & 50.38 & 40.13 & 9.50 & 34.25 & 23.20 & 11.05 & 1.26 & 18.80 & 49.50 & 9.32 & 7.66 & 0.33 \\
\hline & B & 48 to 80 & 28.50 & 45.00 & 26.50 & 38.07 & 21.30 & 16.77 & 1.25 & 25.00 & 41.75 & 8.20 & 15.98 & 0.33 \\
\hline & $\mathrm{C}$ & 80 to 100 & 35.00 & 40.00 & 25.00 & 22.55 & 10.97 & 11.58 & 1.35 & 25.00 & 42.00 & 8.60 & 14.31 & 0.31 \\
\hline & A & 0 to 50 & 48.75 & 41.88 & 9.38 & 34.73 & 24.18 & 10.55 & 1.16 & 18.88 & 51.00 & 18.5 & 9.05 & 0.34 \\
\hline & B & 50 to 77 & 27.50 & 47.25 & 25.25 & 37.60 & 21.56 & 16.05 & 1.28 & 24.00 & 42.25 & 6.80 & 17.75 & 0.34 \\
\hline & $\mathrm{C}$ & 77 to 100 & 37.00 & 39.00 & 24.00 & 23.73 & 14.04 & 9.69 & 1.32 & 25.00 & 40.00 & 8.20 & 16.80 & 0.32 \\
\hline
\end{tabular}


Table 2. Mineralogical composition of the soil horizons

\begin{tabular}{ccl}
\hline & Soil Horizon & \multicolumn{1}{c}{ Minerals } \\
\hline & $\mathrm{O} / \mathrm{A}$ & Quartz, Hematite, Ferrihydrite \\
Quartz, Hematite, Kaolinite, Chlorite, Illite, Smectite \\
\end{tabular}

The color ranged from dark orange to brown to reddish brown, and the Munsell hue ranged from 7.5 YR to 2.5 YR indicating the presence of hematite and ferrihydrite (Torrent et al., 1983; Barron \& Torrent, 1986; Schwertmann, 1988; Boero \& Schwertmann, 1989). Munsell value ranged from 5 to 7 confirming the absence of significant organic matter in the soil. Munsell chroma represents the spectral strength of the color, and the soil in the study area had a bright chroma, indicating well oxidized and well drained soil, however, thin layers of gleyed patches were observed at the interface between the A and B horizons in the cores extracted from eroding sites, which is indicative of poor drainage or seasonally water-logged conditions.
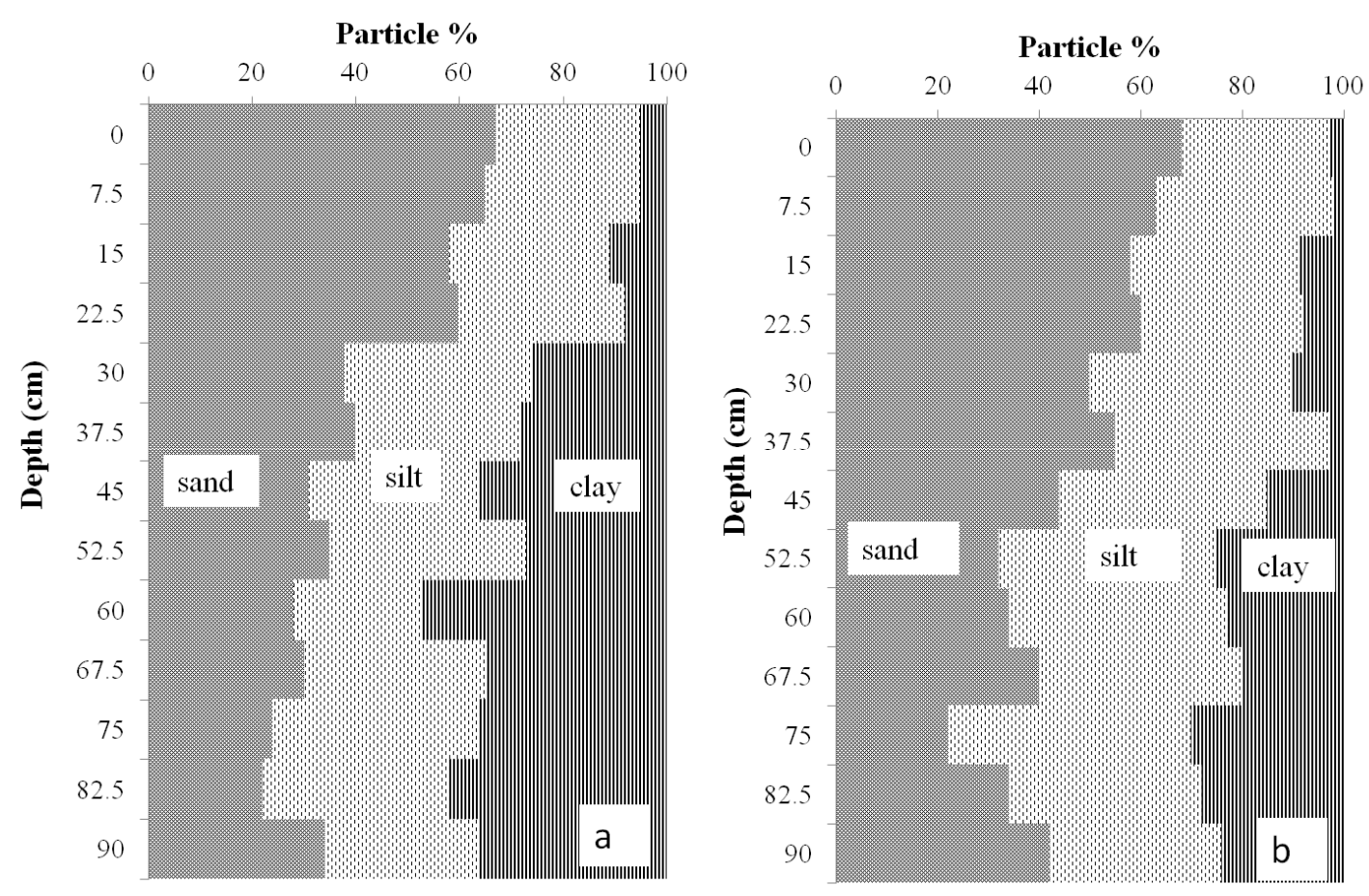

Figure 3. Grain size distribution plot of non-eroded (a) and eroded (b) sites with respect to depth

Atterberg limits does not directly help to identify erosive soils, but studies indicated that high values for Atterberg limits (PL, LL, and PI), are associated with lower soil dispesion and erodibility (Okagbue \& Ezechi, 1988; Igwe \& Ejiofor, 2005). As water content increases in soil, clay and silt become softer, shifting from a solid to a plastic state, and eventually to a liquid state once the soil fails to retain its shape (Yalcin, 2007). Atterberg limits therefore, measure the quantity of water that must enter the soil before it loses coherence, which is an important distinction for hillslope soils that are wetted by infiltration of precipitation, especially when these soils have low infiltration rates associated with the presence of clays. A higher Atterberg limit contributes to soil stability under these conditions (Rienks et al., 2000). The mean plastic limit (PL) values for finer soil in non-eroding and eroding sites were $19.3 \%$ and $22.6 \%$, respectively. The slightly higher average PL observed in this study may be due to the presence of different clay minerals. The liquid limit (LL) and plasticity index (PI) values of non-eroding sites were $35.8 \%$ and $16.4 \%$ respectively, and the LL and PI values of eroding sites were $34.8 \%$ and 
12.2\% respectively. Examination of the plotted LL and PI values on a Casagrande plasticity chart (Figure 4) classified the non-eroding soils as low to medium plasticity clay. About one-third of the soils from eroding sites were plotted below the A-line with a PI of less than 50, indicating the presence of low plasticity silt. The remaining samples were classified as low to medium plasticity clay, described as loose, non-cohesive and prone to erosion by raindrop impact. The Atterburg limits are a function of the distribution of fine grained clays and the clay mineralogy, reflecting the increasing trend of PI with increasing LL, which correlates with increasing clay content in the soil profiles for both eroding $(r=0.601, p=0.001)$ and non-eroding $(r=0.600, p=0.001)$ soils. The samples from both non-eroding and eroding sites are plotted in the kaolinite and illite field in the plasticity chart, confirming the results of the XRD analysis (Figure 4).

\subsection{Soil Bulk Density and Moisture Content}

Due to compaction of the soil cores observed during extraction, a slight overestimation of bulk density was expected in the samples. The bulk density values of non-eroding Ultisols ranged from $1.22 \mathrm{~g} / \mathrm{cc}$ to $1.50 \mathrm{~g} / \mathrm{cc}$ and were significantly greater than bulk densities of the eroding soil $(1.16 \mathrm{~g} / \mathrm{cc}$ to $1.35 \mathrm{~g} / \mathrm{cc})(\mathrm{p}<0.000)$. The bulk density of the non-eroding soil gradually increased with depth, while in comparison, the bulk density of the eroding soil was nearly constant to a depth of $50 \mathrm{~cm}$ (19.68 in), at which point it increased abruptly (Figure 5a and $b)$. This change correlated positively with changes in soil clay content $(r=0.777, p<0.000)$ and negatively with Ks $(\mathrm{r}=-0.774, \mathrm{p}<0.000)$.

Although moisture content is a highly variable parameter, both spatially and temporally, soil moisture has a significant impact on surface runoff and erosion, whether by runoff due to saturation or by runoff associated with rainfall rates exceeding infiltration rates (Wei, 2007). Gullying is a consequence of severe water erosion (Brooks et al., 1997), and as a result, soil moisture content is an important parameter to consider in sites where erosion is present, because moisture content is one factor governing surface runoff. Internal cohesion of soil is reduced by lack of moisture, and dry aggregates are broken down by raindrop impact into fines that seal surface pores, reduce infiltration and increase runoff (Wei, 2007). In this manner, the soil becomes vulnerable to water erosion (Zhang et al., 2011). While we recognize that soil moisture is a variable parameter in both space and time, because all four cores were extracted in a two-hour time window, diurnal variations in soil moisture are not a factor. Differences in soil moisture between the eroding and non-eroding sites can provide clues to the connection between antecedent moisture conditions and erosion at this site. On average, soil samples from the eroding sites had slightly lower moisture content than soil samples from the non-eroding sites $(22 \%$ and $24.54 \%$, respectively). Moisture content varied with depth for both the eroding $(\mathrm{r}=0.829, \mathrm{p}<0.000)$ and non eroding $(\mathrm{r}=0.783, \mathrm{p}<0.000)$ sites; the soil moisture in the topsoil horizons was significantly higher than the soil moisture in the lower horizons for both the eroding $(\mathrm{p}=0.005)$ and non-eroding $(\mathrm{p}<0.000)$ soils (Figure 6a and $\mathrm{b}$ ). With depth, the moisture content decreased slightly, and then gradually increased in the B horizons. This increase correlated with the percent clay in the soil $(r=0.770, \mathrm{p}<0.000)$. 


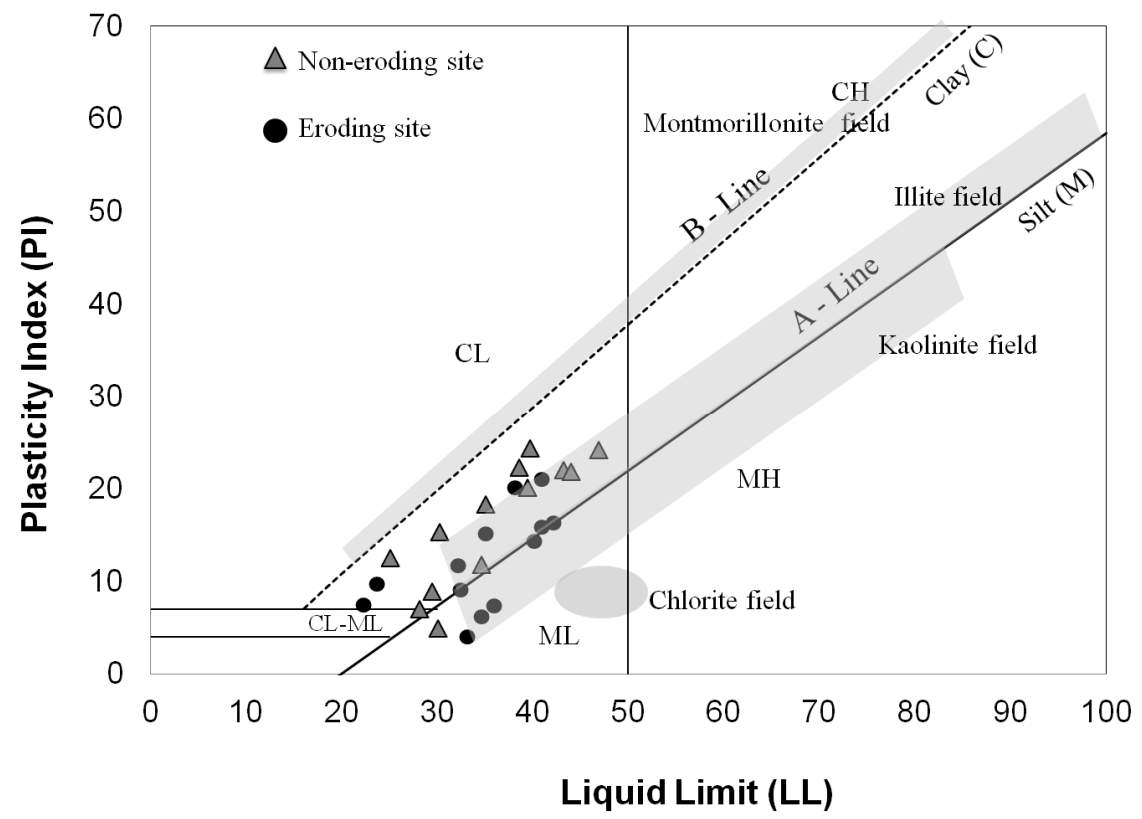

Figure 4. Atterberg limits of soils from non-eroded and eroded sites. Figure indicates the field of clay minerals

\subsection{Porosity, Hydraulic Conductivity, Swelling and Erodibility Factor}

Soil porosity can be an indication of soil aggregation, because soil aggregates provide pore space for the storage and exchange of water and air. The larger the aggregate, the higher the porosity, and the easier it is for water to infiltrate and percolate through the soil horizons. The stability of the soil aggregates is paramount, because raindrop impact can dislodge soil particles in poorly aggregated soil. If the dislodged particles are fine enough they are transported through eluviation to lower horizons, and accumulate in an illuviation zone associated with the B horizon. Larger dislodged particles may clog soil pores near the surface, forming a low permeability crust that reduces infiltration and impedes water movement through the soil (Wei, 2007). Average soil porosity was higher for the eroding site $(47.5 \%)$ than for the non-eroding site $(40.7 \%)(\mathrm{p}<0.000)$. For the eroding site, soil porosity was correlated with depth over all horizons $(\mathrm{r}=0.703, \mathrm{p}<0.000)$. Specifically, porosity in the topsoil, where the majority of the soil erosion was occurring, was significantly higher (45\% to $56 \%$ ) than soil porosity in the $\mathrm{B}$ and $\mathrm{C}$ horizons $(\mathrm{p}<0.000)$. The field observation indicated that soil samples from both sites had a granular structure, and macroporosity associated with a well-structured soil was lacking.

A soil generally has $50 \%$ of its pores filled with air and the other $50 \%$ with water (Brady \& Weil, 2008), and the soil in the non-eroding sites demonstrated the relationship (Figure 6a) with moisture content approximately equal to half of porosity. This relationship does not hold true in the eroded soil, especially in the A horizon, where high porosity was correlated to reduced soil moisture content $(\mathrm{r}=-0.827, \mathrm{p}<0.000)$, possibly because increased porosity resulted in increased drainage, which led to drier conditions in the A horizon (Figure 6b). Low moisture content in the A horizon can be linked to the low clay and organic content of the soils, because the presence of clays and organic material tends to increase soil moisture content (Brady \& Weil, 2008). Low clay content, low organic content, and low moisture content conditions are not conducive to favorable vegetation and biological activity, and as the situation persists, the site will become even more susceptible to gully erosion.

Ks is a measure of how well water can move through the soil; a useful parameter for land management. In the non-eroding site, Ks ranged from 5.41 to $15.7 \mathrm{~m} /$ day ( 17.7 to $51.5 \mathrm{ft} /$ day), with an average of $8.50 \mathrm{~m} /$ day ( 27.8 $\mathrm{ft} / \mathrm{day})$. Cores from the non-eroding site did not show significant fluctuation in Ks with depth $(\mathrm{p}=0.13)$. In contrast, Ks for samples from the eroding site was correlated with depth $(\mathrm{r}=0.780, \mathrm{p}<0.000)$. In the A horizon, Ks ranged from 9.32 to $18.5 \mathrm{~m}$ /day ( 30.57 to $60.7 \mathrm{ft} /$ day), related to the high porosity and high erosion rate consistent with this horizon. In the B horizon Ks dropped to 6.8 to $8.2 \mathrm{~m} /$ day (22.3 to $26.9 \mathrm{ft} /$ day) (Figure $5 \mathrm{a}$ and b). This abrupt vertical change in Ks has been linked to gully erosion, because high Ks coupled with high porosity gives rise to high infiltration rate and flow velocity in the A horizon (Lin et al., 1999; Blanco-Canqui et al., 2002; Igwe \& Ejiofor, 2005; Kutílek et al., 2006), however when percolating water reaches the B horizon, an abruptly lower Ks halts the downward movement of water and builds up an upward pore pressure, favoring 
internal erosion and piping (Rooyani, 1985; Yaalon, 1987). An obvious, negative correlation was observed between bulk density and $\mathrm{Ks}(\mathrm{r}=-0.774, \mathrm{p}<0.000)$ (Figure $5 \mathrm{a}$ and $\mathrm{b}$ ).

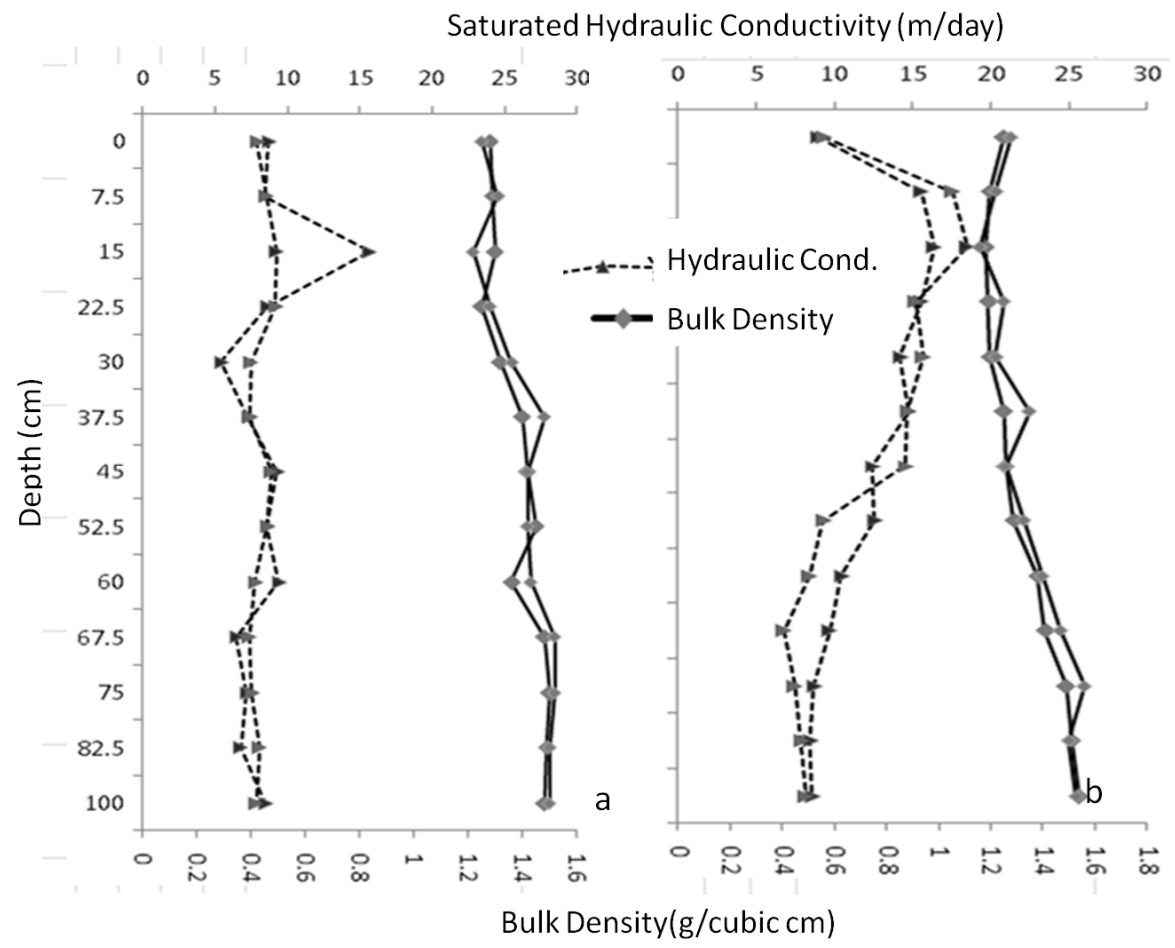

Figure 5. Change in bulk density and Ks of soils in non-eroded (a) and eroded (b) sites with depth

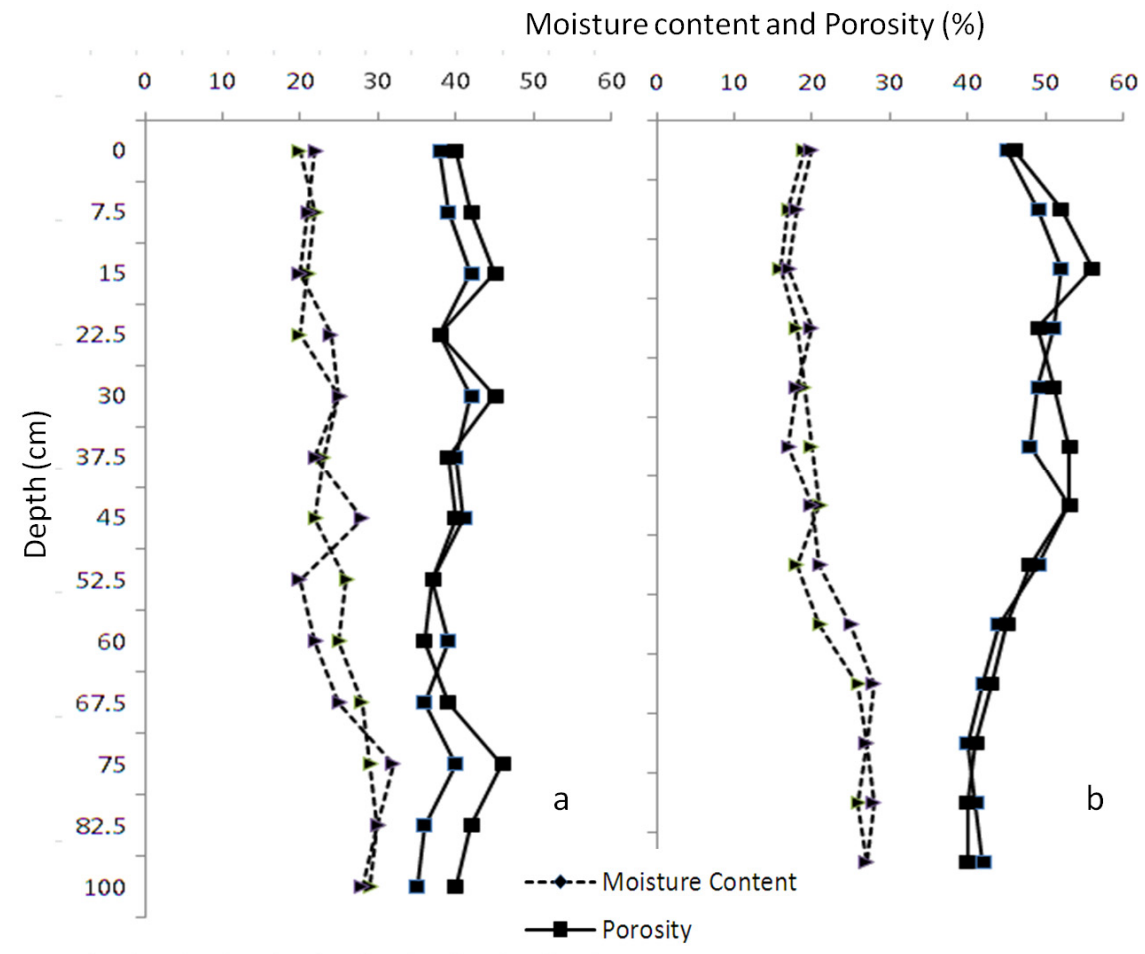

Figure 6. Change in moisture content and porosity of soils in non-eroded (a) and eroded (b) sites with depth 
A soil's clay content plays an important factor in the formation of soil aggregates, and reinforces soil stability, however, clays with a high swelling potential can have the opposite effect on soil stability. If expansive clays are present, these minerals will swell in the presence of water, and will shrink in dry conditions. Repeated shrink-swell cycles may destroy the clay aggregation and lead to further erosion (Chappell et al., 1999; Emami \& Ghazavi, 2002; Bronick \& Lal, 2004). Further, in dry conditions, clay can shrink, producing internal cracks which may facilitate tunnel or piping erosion. When heavy rainfall occurs, runoff enters the cracks and erodes the soil from within. The tunnels or pipes eventually develop into gullies when the tunnel roof collapses (Crouch et al., 1986; Rienks, et al., 2000). Field observations of the site indicated headward erosion of existing gullies through collapse of tunnels or pipes as subsurface runoff emerged spring-like at the head of a gully, similar to channel-head retreat observed in eroding tropical Ultisols (Chappell et al., 1999).

The swelling potential in eroding sites was low with an average of $12.18 \%$. In the non-eroding sites, noticeable swelling was observed within the depth of 30 to $60 \mathrm{~cm}$ (11.8 to $23.6 \mathrm{in}$ ), which ranged from 25.3 to $35.8 \%$ (Figure $7 \mathrm{a}$ and $\mathrm{b}$ ). The swelling property of soil was significantly correlated to the clay content $(\mathrm{r}=0.770$, $\mathrm{p}<0.000$ ) hence the eroded soil with lower clay content had correspondingly lower swelling potential. The clay mineralogy is also important as some mixed layer kaolinite-smectite was found in the B horizon of the non-eroding soil.



Figure 7. Change in \% swelling of soils in non-eroded (a) and eroded (b) sites with depth

The soil erodibility factor was estimated using soil texture, organic matter, soil structure and Ks of the soil. In the study area the average soil erodibility factor for the non-eroding site was 0.27 , and for the eroding site was 0.33 , where a higher value for soil erodibility factor indicates a higher susceptibility to erosion. These values are consistent with the reported average value of 0.28 for Collegedale-Etowah series. The higher erodibility factor in the eroding site indicates that once erosion has begun, the soil become less resistant to future erosion. For the non-eroding sites, $\mathrm{K}$ decreased noticeably below the $\mathrm{B}$ horizon, whereas for the eroding sites soil erodibility factor was constant except for a small increase in the upper portion of the B horizon. This increase can be due to a combined effect of increased silt content and reduced Ks in the samples.

\subsection{Soil Mineralogy and Geochemistry}

Mineralogical differences between the non-eroding and eroding soils using XRD analysis were trivial. Quartz was prevalent in all soil horizons, and at both eroding and non-eroding sites, the soil contained silicate clay such as chlorite, illite, and kaolinite. Chemical weathering of carbonate minerals yields a non-carbonate fraction, 
including silicate minerals (derived from allogenic materials like loess, colluvium, and alluvium, or present as impurities within the carbonate bedrock). This non-carbonate fraction produces a thick clay-rich soil cover, and the type of clay minerals present has an impact on the severity of the gully erosion (Boero, 1989). Following glycolation, the clays from the B horizon of the non-eroding sites contained a mixed kaolinite-smectite layer, indicating expansive properties, however expanding clays were absent in the eroding sites. This absence can be explained by the removal of fine-grained sediment by raindrop impact, stormwater runoff and gully wall slumping. The saprolite-dominated $\mathrm{C}$ horizon from both eroding and non-eroding sites had a similar mineral assemblage with the additional presence of relic carbonate from the underlying bedrock. The XRD result was confirmed with Atterberg limit plot (Figure 4), where the soils plotted in the illite and kaolinite field of the plasticity chart (Casagrande, 1948). XRD analysis indicated the presence of hematite in the clay fraction, and broadening of the diagnostic hematite XRD peaks indicates a low degree of crystallinity. The presence of sparingly soluble iron oxides like hematite and ferrihydrite in Ultisols, gives the soil its characteristic bright red color (Boero \& Schwertmann, 1989). Ferrihydrite, however, was not detected by XRD, probably due to its amorphous crystal structure. The presence of kaolinite and iron oxide are indicators of ongoing weathering consistent with lateralization that decreases soil stability (Constantini et al., 2002).

The XRD studies were complemented by scanning electron microscopy (SEM) augmented with energy-dispersive X-ray (EDX) microanalysis. EDX results indicate that elements such as $\mathrm{O}, \mathrm{Si}, \mathrm{Al}, \mathrm{Ca}, \mathrm{Fe}$, and $\mathrm{Mg}$ are prolific in the soil samples. The analysis was performed on several samples from eroding and non-eroding sites, and two representative spot analysis results are presented. B horizon samples from both the eroding and non-eroding sites contain kaolinite clay minerals, identified from their crystalline structure and elemental composition. The EDX analysis established that the kaolinite and illite crystals were coated with granular hematite, resulting in the destruction of the clay minerals' crystalline structure when iron oxide bonded to the colloids, producing granular micro-aggregates (Figure 8). SEM results from the saprolite layer (C horizon) in Figure 9 indicate the presence of relic rhombohedral calcite crystals surrounded by iron-coated clay minerals. This observation was confirmed by the EDX elemental analysis.

\subsection{Soil $p H$ and Macronutrients}

Soil $\mathrm{pH}$ has not been shown to directly affect gully erosion, however, a correlation between a change in soil $\mathrm{pH}$ and erosion processes has been observed (Gachene et al., 1997). Soil acidification is related to a loss of soil quality; when vegetation is unable to flourish in acidic soil, it may die, its roots will no longer retains the soil, and soil erosion will commence. A low pH in the range of $4.5-6.0$ in the A horizon was found in both eroding and non-eroding sites. The $\mathrm{pH}$ increased slightly with depth at the interface of $\mathrm{B}$ and $\mathrm{C}$ horizons, and in the $\mathrm{C}$ horizon. This was due to the natural liming effect of the limestone bedrock. The average CEC of the eroding site samples was significantly lower $(12.30 \mathrm{cmol} / \mathrm{kg})$ than the soils in the non eroding sites $(21.04 \mathrm{cmol} / \mathrm{kg})$ $(p<0.000)$. Low CEC in the eroding sites can be explained by erosion-induced changes in organic matter and clay content of the A horizon. The depth profile distribution of CEC was characterized by a slightly increased trend with soil depth due to change in soil texture and clay concentration in both eroding and non-eroding soil.

Ultisols in the study site were non-fertile with relatively low concentrations of essential plant nutrients. The major macronutrients (Nitrogen, Phosphorous, and Potassium) were low in both sites, and Nitrogen and Potassium were significantly lower in the eroded soil in comparison to the non-eroded soil ( $<<0.000$ for both). This is a direct result of the soil texture; nutrients did not adhere to the coarse soil grains and were washed away with the finer clay colloidal particles in the gully area. With the exception of the surface horizon of the non-eroding site, Nitrogen concentration was low throughout the profile. This slightly increased Nitrogen concentration at the surface was most likely due to the site's previous use as pasture and grazing land. Likewise, Potassium and Phosphorous concentrations were increased at the transition between the A and B horizons, because the finer clay in the B horizon assists in nutrient retention. 


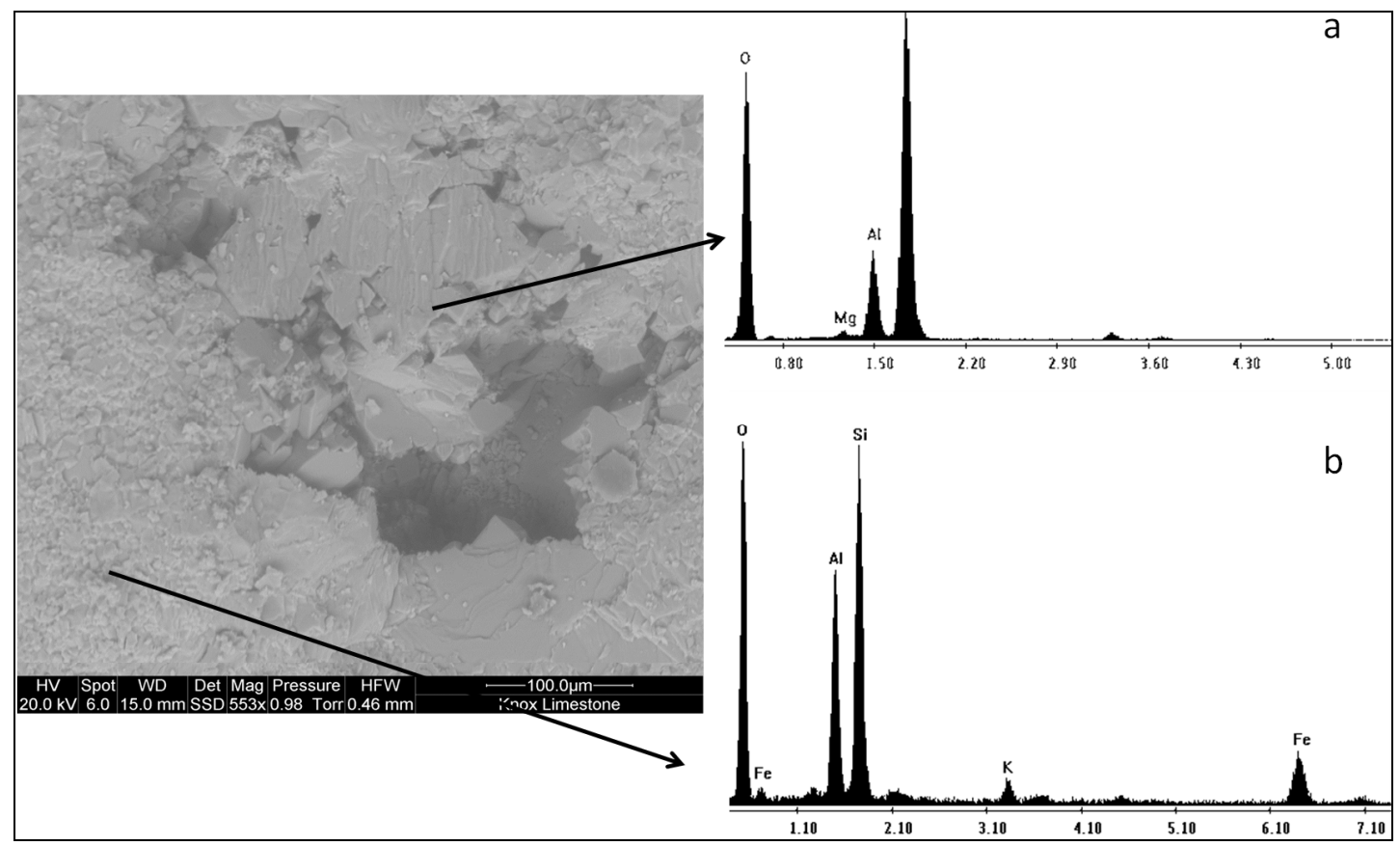

Figure 8. The SEM image and EDX analysis indicate presence of crystalline kaolinite clay in B horizon of one non-eroding site soil sample (a). Presence of granular hematite was confirmed from iron peak which coated the kaolinite and illite crystals (b)

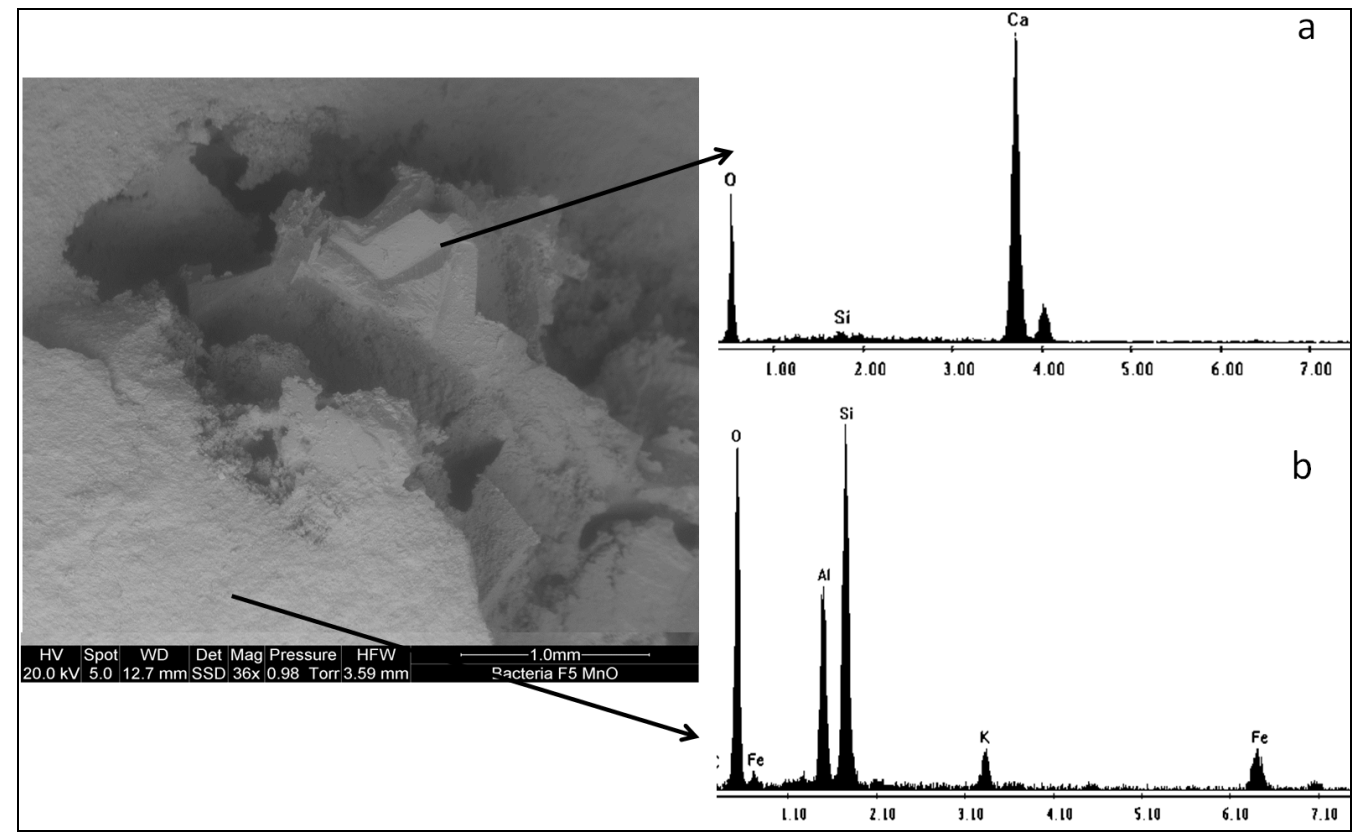

Figure 9. The SEM image and EDX analysis from saprolite layer (C horizon) indicate the presence of relic rhombohedral calcite crystal (a) surrounded by iron-coated clay minerals (b)

\section{Conclusion}

The physico-chemical properties of Ultisols derived from Ordovician to Cambrian aged, siliceous dolomite and magnesian limestone were investigated to evaluate the interaction of gully erosion and soil properties. Soils from eroding and non-eroding sites were sampled, and the following physico-chemical properties were measured: clay mineralogy, $\mathrm{pH}, \mathrm{CEC}$, macronutrients (Nitrogen, Potassium, and Phosphorus), PSD, Atterburg limits, bulk density, moisture content, porosity, Ks, soil erodibility factor, and swelling potential. 
The field analysis of the soil profiles indicated obvious soil horizons, and four soil horizons were identified. The soil texture ranged from sandy loam, loam to clay loam and silty clay loam. Differences in the physico-chemical properties of soil profiles in the eroding verses non-eroding sites were related to gully erosion. The average clay and silt content, porosity, moisture content, Ks, soil erodibility factor, Atterberg limit values, and swelling potential had significant differences between eroded and non-eroded sites $(\mathrm{p}<0.05)$. In contrast, erosion status was not significantly correlated to sand content, bulk density, soil color, $\mathrm{pH}, \mathrm{CEC}$, nor macronutrient content. Statistically significant correlations were identified between clay content and Atterberg limits, bulk density, Ks, and swelling potential.

Because there are differences in soil physico-chemical properties between the non-eroding and the eroding site, land management strategies to restore the land and halt the erosion should consider these differences when selecting appropriate restoration methods. Seedlings that thrive in the non-eroding soils may not become established in the eroding soils due to active erosion and differences in porosity, particle size distribution, Ks, moisture content, and soil fertility. Hard mitigation measures such as construction of berms to redirect runoff away from eroding sites, construction of detention ponds to reduce surface runoff, and soil upgrading and back sloping to reduce slumping on steep slopes have the potential to reduce future gully erosion. Soft mitigation measures such as seeding and mulching after applying fertilizer can help to improve soil stability and fertility and restore eroded areas. The applicability of the various hard and soft mitigation strategies for protection and restoration of the gullied area needs further evaluation. Also needing further evaluation is the role of topography, rate of change of slope, presence of exposed bedrock or transported boulders, local drainage patterns, soil thickness, and rainfall intensity on soil properties and erosion.

\section{Acknowledgements}

The authors would like to express sincere thanks to Dr. Cynthia Luitkus and Dr. Guichuan Hou of Appalachian State University for the help in SEM studies, Dr. Edith Seier for the input in statistical evaluation, and to the reviewers for their comments and suggestions.

\section{References}

Amézketa, E. (1999). Soil aggregate stability: a review. Journal of Sustainable Agriculture, 14(2), 83-151. http://dx.doi.org/10.1300/J064v14n02_08

ASTM. (1996). Annual Book of ASTM Standards, Section 4, Construction, 4.08 Soil and Rock (I): D420-D4914 ASTM, West Conshohocken, Pa.

Barron, V., \& Torrent, J. (1986). Use of Kubelka-Munk theory to study the influence of iron oxides on soil colour. Journal of Soil Science, 37, 499-510. http://dx.doi.org/10.1111/j.1365-2389.1986.tb00382.x

Battaglia, S., Leoni, L., \& Sartori, F. (2002). Mineralogical and grain size composition of clays developing calanchi and biancane erosional landforms. Geomorphology, 49, 153-170. http://dx.doi.org/10.1016/S0169-555X(02)00171-X

Blake, G. R., \& Hartge, K. H. (1986). Bulk density. In A. Klute (Ed.), Methods of soil analysis. Part 1. Physical and mineralogical methods (2nd ed., pp. 363-382). Agronomy Monograph, Madison, WI.

Boero, V., \& Schwertmann, U. (1989). Iron oxide mineralogy of terra rossa and its genetic implications. Geoderma, 44, 319-327. http://dx.doi.org/10.1016/0016-7061(89)90039-6

Brady, N. C., \& Weil, R. R. (2008). The Nature and Properties of Soils (14th ed.). Pearson-Prentice Hall, Upper Saddle River, NJ.

Bronick, C. J., \& Lal, R. (2004). Soil structure and management: a review. Geoderma, 124(1-2), 3-22. http://dx.doi.org/10.1016/j.geoderma.2004.03.005

Brooks, K. N., Ffolliott, P. F., Gregersen, H. M., \& DeBano, L. F. (1997). Hydrology and the management of watersheds (2nd ed.). Ames, IA: Iowa State University Press.

Bryan, R., \& Yair, A. (1982). Perspectives on studies of badland geomorphology. In Bryan, R., \& Yair, A. (Eds.), Badland geomorphology and piping (pp. 1-13). Norwich: Geo Books.

Casagrande, A. (1948). Classification and identification of soils. Transactions of the American Society of Civil Engineers, 113, 901-930.

Cauley, M. (1986). Benchmark soils of Lesotho: their classification, interpretation, use and management. Office of Soil Survey, Soil Conservation Division Ministry of Agriculture: Maseru.

Cerda, A. (2002). The effect of season and parent material on water erosion on highly eroded soils in eastern 
Spain. Journal of Arid Environment, 52, 319-337. http://dx.doi.org/10.1006/jare.2002.1009

Chappell, N. A., Ternan, J. L., \& Bidin, K. (1999). Correlation of physicochemical properties and sub-erosional landforms with aggregate stability variations in a tropical Ultisol disturbed by forestry operations. Soil Tillage and Research, 50, 55-71. http://dx.doi.org/10.1016/S0167-1987(98)00196-2

Costantini, E. A. C., Angelone, M., \& Napoli, R. (2002). Soil geochemistry and pedological processes; The case study of the quaternary soils of the Montagnola Senese (Central Italy): Il Quaternario. Italian Journal of Quaternary Sciences, 15(1), 111-120.

Crouch, R. J., McGarity, J. W., \& Storrier, R. R. (1986). Tunnel formation processes in the riverina area of N. S. W., Australia, Earth Surf. Processes Landforms, 11, 157-168. http://dx.doi.org/10.1002/esp.3290110206

Danielson, R. E., \& Sutherland, P. L. (1986). Porosity. IN: Methods of Soil Analysis, Part1 (A. Klute, ed) Madison, WI: Am. Soc. Agron., 443-461.

Emami, J., \& Ghazavi, A. (2002). Landslides and ruptures in saturated fine soils of Chaharmahal and bakhtiari province of Iran. J. of Earth Sci. 35, 42-44.

Faulkner, H. (2006). Piping hazard on dispersive and collapsible soils in Europe. In Poesen, J., Boardman, J. (Eds.), Soil and Gully Erosion in Europe, 537-566.

Fistikoglu, O., \& Harmancioglu, N. B. (2000). Integration of GIS with USLE in Assessment of Soil Erosion. Water Resources Management, 16, 447-467. http://dx.doi.org/10.1023/A:1022282125760

Gachene, C. K. K., Jarvis, N. J., Linner. H., \& Mbuvi, J. P. (1997). Soil erosion effects on soil properties in a highland area of central Kenya. Soil Sci. Soc. Am. J., 61, 559-564. http://dx.doi.org/10.2136/sssaj1997.03615995006100020027x

Humberto Blanco-Canqui, C. J., Gantzer, S. H., Anderson, E. E., Alberts, \& Ghidey, F. (2002). Saturated Hydraulic Conductivity and Its Impact on Simulated Runoff for Claypan Soils. Soil Science Society of America Journal, 66, 1596-1602.

Igwe, C. A., \& Ejiofor, N. (2005). Structural stability of exposed gully wall in Central Eastern Nigeria as affected by soil properties. International Agrophysics, 19, 215-222.

Imeson, A. C., Kwaas, F. J. P. M., \& Verstraten, J. M. (1982). The relationship of soil physical and chemical properties to the development of badlands in Morocco. In Bryan, R., \& Yair, A. (Eds.), Badland geomorphology and piping, 47-69. Norwich: Geo Books.

Ingles, O. G., \& Aitchson, B. (1969). Soil-water disequilibrium as a cause of subsidence in natural soils and earth embankments. Proceeding of Tokyo Symposium International Association of Hydrological Sciences, United Nations Economic. Social and Cultural Organization Tokyo, 11, 342-352.

IS: 2720. (1997). Indian Standard methods of test for soils, Determination of free swell index of soils, Bureau of Indian Standards, Manak Bhavan, New Delhi.

Jegede, G. (2000). Effect of soil properties on pavement failures along the F209 highway at Ado-Ekiti, south-western Nigeria. Constr. Build. Mater. P., 14, 311-315. http://dx.doi.org/10.1016/S0950-0618(00)00033-7

Kutílek, M., L., Jendele, K. P., \& Panayiotopoulos. (2006). The influence of uniaxial compression upon pore size distribution in bi-modal soils. Soil Till. Res., 86, 27-37. http://dx.doi.org/10.1016/j.still.2005.02.001

Lal, R. (2001). Soil Degradation by erosion. Land degradation and development, 12, 519-539. http://dx.doi.org/10.1002/ldr.472

Lin, H. S., McInnes, K. J., Wilding, L. P., \& Hallmark, C. T. (1999). Effects of soil morphology on hydraulic properties I. Quantification of soil morphology. Soil Science Society of America Journal, 63, 948-954. http://dx.doi.org/10.2136/sssaj1999.634948x

Liu, G., Xua, M., \& Ritsema, C. (2003). A study of soil surface characteristics in a small watershed in the hilly, gullied area on the Chinese Loess Plateau. Catena, 54, 31-44. http://dx.doi.org/10.1016/S0341-8162(03)00055-9

Lobo, D., Lozano, Z., \& Delgado, F. (2005). Water erosion risk assessment and impact on productivity of a Venezuelan soil. Catena, 64(2-3), 297-306. http://dx.doi.org/10.1016/j.catena.2005.08.011

Moore, H. L. (1976). Drainage problems in carbonate terrain of East Tennessee. In Proceedings of 27th Annual Highway Geology Symposium: Orlando, FL, 112-131. 
Nearing, M. A., Wei, H., Stone, J. J., Pierson, F. B., Spaeth, K. E., Weltz, M. A., \& Flanagan, D. C. (2005). A Rangeland Hydrology and Erosion Model. Transactions of the American Society of Agricultural and Biological Engineers, 54, 1-8.

Nizeyimana, E., \& Olson, K. R. (1988). Chemical, mineralogical, and physical differences between moderately and severely eroded Illinois soils. Soil Science Society of America Journal, 52, 1740-1748. http://dx.doi.org/10.2136/sssaj1988.03615995005200060041x

Nordström, K. (1988). Gully erosion in the Lesotho lowlands - a geomorphological study of the interactions between intrinsic and extrinsic variables. Department of Physical Geography, Uppsala University, UNGI Report No. 69.

Oades, J. M., \& Waters, A. G. (1991). Aggregate hierarchy in soils. Australian Journal of Soil Research, 29 , 815-828. http://dx.doi.org/10.1071/SR9910815

O'Geen, A. T., \& Schwankl, L. J. (2006). Understanding Soil Erosion in Irrigated Agriculture. Regents of the University of California, Division of Agriculture and Natural Resources. Publication 8196.

Okagbue, C. O., \& Ezechi, J. I. (1988). Geotechnical characteristics of soils susceptible to severe gullying in Eastern Nigeria. Bulletin Int. Assoc. Eng. Geol., 38, 111-119.

Okagbue, C. O., \& Uma, K. O. (1987). Performance of gully ersion control measures in southern Nigeria. Proceeding of international symposium of forest hydrology and watershed management, Vancouver, Canada, IAHS Publication, No. 167, 163-172.

Piccarreta, M., Faulkner, H., Bentivenga, M., \& Capolongo, D. (2006). The influence of physico-chemical material properties on erosion processes in the badlands of Basilicata. Southern Italy. Geomorphology, 81, 235-251. http://dx.doi.org/10.1016/j.geomorph.2006.04.010

Pimentel, D. (2000). Soil erosion and the threat to food security and the environment. Ecosystem Health, 6, 221-226. http://dx.doi.org/10.1046/j.1526-0992.2000.006004221.x

Ramezanpour, H., Esmaeilnejad, L., \& Akbarzadeh, A. (2010). Influence of soil physical and mineralogical properties on erosion variations in Marlylands of Southern Guilan Province, Iran. International Journal of Physical Sciences, 5(4), 365-378.

Rienks, S. M., Botha, G. A., \& Hughes, J. C. (2000). Some physical and chemical properties of sediments exposed in a gully donga in northern KwaZulu-Natal, South Africa and their relationship to the erodibility of the colluvial layers. Catena, 39, 11-31. http://dx.doi.org/10.1016/S0341-8162(99)00082-X

Rooyani, F. (1985). A note on soil properties influencing piping at the contact zone between albic and argillic horizons of certain duplex soils (Aqualfs) in Lesotho, southern Africa. Soil Science, 139, 517-522. http://dx.doi.org/10.1097/00010694-198506000-00007

Rhoton, F. E., \& Tyler, D. D. (1990). Erosion induced changes in the properties of a Fragipan soil. Soil Science Society of America Journal, 54, 223-228. http://dx.doi.org/10.2136/sssaj1990.03615995005400010035x

Santis, F. D., Giannossi, M. L., Medici, L., Summa, V., \& Tateo, F. (2010). Impact of physico-chemical soil properties on erosion features in the Aliano area (Southern Italy). Catena, 81, 172-181. http://dx.doi.org/10.1016/j.catena.2010.03.001

Schwertmann, U. (1988). Some properties of soil and synthetic iron oxides: in Iron in Soils and Clay Minerals, Nato Advanced Study Institute, J. W. Stucki, B. A. Goodman, and U. Schwertmann, eds., Reidel Publishing Company, Dordrecht, Holland, 203-250.

Singh, H. N., \& Prakash, O. (2000). Characteristics and erodibility of some degraded soils of the hill region of Uttar Pradesh. Agropedology, 10, 101-107.

Smith, H. J., Van Zyl, A. J., Claassens, A. S., Schoeman, J. L., \& Laker, M. C. (2000). Soil loss modelling in the Lesotho Highlands Water Project catchment areas. South African Geography Journal, 82, 64-69. http://dx.doi.org/10.1080/03736245.2000.9713694

S \& ME, Inc. (2010). Phase I Environmental Site Assessment Former Valleybrook Farm, 142 Pickens Road, Washington County, Tennessee.

Stiles, C. A., \& Stensvold, K. A. (2008). Pedology - Loess Contribution to Soils Forming on Dolostone in the Driftless Area of Wisconsin. Soil Science Society of America Journal, 72(3), 650-660. http://dx.doi.org/10.2136/sssaj2007.0112 
Summa, V., Tateo, F., Medici, L., \& Giannossi, M. L. (2007). The role of mineralogy, geochemistry and grain size in badland development in Pisticci (Basilicata, Southern Italy). Earth Surface Processes Landform, 32, 980-997. http://dx.doi.org/10.1002/esp.1449

Torrent, J., Schwertmann, U., Fechter, H., \& Alferez, F. (1983). Quantitative relationships between soil color and hematite content. Soil Sci., 136, 354-358. http://dx.doi.org/10.1097/00010694-198312000-00004

Torri, D., Colica, A., \& Rockwell, D. (1994). Preliminary study of the erosion mechanisms in biancane badland (Tuscany, Italy). Catena, 23, 281-294. http://dx.doi.org/10.1016/0341-8162(94)90073-6

USDA, United States Department of Agriculture, Natural Resources Conservation Service (NRCS). (2004). Soil Survey Staff. Soil Taxonomy (2nd Ed.). Washington.

USDA, United States Department of Agriculture, Web Soil Survey, Washington County Soil Survey Report (2011). Washington.

U. S. Environmental Protection Agency, Tennessee Water Quality Assessment Report (2012). Retrieved from http://iaspub.epa.gov/waters10/attains_state.control?p_state $=T N \& p \_c y c l e=2010$.

U. S. Environmental Protection Agency, National Summary of Impaired Waters and TMDL Information. (2012). Retrieved from http://iaspub.epa.gov/waters10/attains_nation_cy.control?p_report_type=T\#status_of_data

Van-Zijl, G. M. (2010). An investigation of the soil properties controlling gully erosion in a sub-catchment in Maphutseng, Lesotho, unpublished thesis, Stellenbosch University.

Wei, L., Zhang, B., \& Wang, M. (2007). Effects of antecedent soil moisture on runoff and soil erosion in alley $\begin{array}{lllll}\text { cropping } & \text { systems. }\end{array}$ http://dx.doi.org/10.1016/j.agwat.2007.08.007

Weil, R. R. (2005). Laboratory Manual for Introductory Soils (7th Ed.). Dubuque, IA: Kendall/Hunt.

Yaalon, D. H. (1987). Is gullying associated with highly sodic colluvium? Further comment to the environmental interpretation of southern african dongas. Palaeogeography, Palaeoclimatology, Palaeoecology, 58, 121-123. http://dx.doi.org/10.1016/0031-0182(87)90010-1

Yalcin, A. (2007). The effects of clay on landslides: A case study. Applied Clay Science, 28, 77-85. http://dx.doi.org/10.1016/j.clay.2007.01.007

Zhang, X. Y., Gong, S. L., Shen, Z. X., Mei, F. M., Liu, L. C. , Zhou, Z. J., ... Cheng, Y. (2003). Characterization of soil dust aerosol in China and its transport and distribution during 2001 ACE-Asia. Journal of Geophysical Research, 108(9), 4261-42613. http://dx.doi.org/10.1029/2002JD002632

Zhang, Y., Wei, H., \& Nearing, M. A. (2011). Effects of antecedent soil moisture on runoff modeling in small semiarid watersheds of southeastern Arizona. Hydrology Earth System Science, 15, 3171-3179. http://dx.doi.org/10.5194/hessd-8-6227-2011 